\title{
Ultrasonic Bonding Interface Degradation Characteristics of Gold-Coated Silver Wire for Semiconductor Packaging
}

\author{
반도체 패키징용 금 코팅된 은 와이어의 초음파 접합부 열화 특성 \\ Mi-Song Kim*, Won Sik Hong*, ${ }^{*}$, Sang Yeop Kim**, Sung Min Jeon**, \\ and Jeong Tak Moon** \\ *Electronic Convergence Materials \& Device Research Center, Korea Electronics Technology Institute, \\ Seongnam, 13509, Korea \\ **Material Development Team, R\&D Center, MK ELECTRON CO., LTD., Yongin, 17030, Korea
}

†Corresponding author: wshong@keti.re.kr

(Received June 14, 2021; Revised June 22, 2021; Accepted June 25, 2021)

\begin{abstract}
Gold-coated silver wire was developed to alleviate the high cost of Au wire used in semiconductor packaging. Ball-bonding and stitch-bonding techniques were used to fabricate the dummy packaging material, comprising $97.3 \%$ $\mathrm{Ag}, 97.3 \% \mathrm{Au}$-Coated Ag, and $99.99 \% \mathrm{Au}$ wires. The wire ball shear test (BST), the wire ball pull test (BPT), and the microstructural attributes of the ultrasonic bonding interfaces were compared with the initial properties, both before and after the highly accelerated stress test (HAST), conducted at $130{ }^{\circ} \mathrm{C}$ and $85 \%$ relative humidity (RH). The initial bonding strength for all the wire variants was $\approx 23 \sim 24$ gf. Following the HAST, the bonding strength of the Ag wire, the $\mathrm{Au}$-coated $\mathrm{Ag}$ wire, and the $\mathrm{Au}$ wire decreased by approximately $75 \%, 47 \%$, and $17 \%$, respectively. The microstructure analysis revealed that cracks developed and propagated at the ends of the interface and that the Au-rich Au-Al intermetallic compound (IMC) inhibited the propagation of the crack at the ACA/Au wire interface. Additionally, it was discovered that the presence of the Ag-Au-Al IMC at the interface of the ACA wire reduced Kirkendall voids, which act as a barrier to Au-Al interdiffusion.
\end{abstract}

Key Words: Bonding wire, Ag wire, Au coated Ag wire, HAST, Wire ball shear strength

\section{Introduction}

Bonding wires transmit signals from various semiconductor devices such as integrated circuits, radio frequency (RF), field-programmable gate array (FPGA), light-emitting diode (LED), and memory package. It is important to select bonding wires of materials with excellent corrosion resistance and bonding degradation properties since the efficiency and reliability of semiconductor modules can be directly affected. Materials for bonding wires include gold $(\mathrm{Au})$, silver $(\mathrm{Ag})$, aluminum $(\mathrm{Al})$, copper $(\mathrm{Cu})$, palladium-coated copper (Pd-coated $\mathrm{Cu}$ ), palladium-doped copper (Pd-doped $\mathrm{Cu})$, and gold-coated copper (Au-coated $\mathrm{Cu}$ ), while $\mathrm{Au}$ wires with the best corrosion resistance have been used most commonly. In addition to corrosion resistance, $\mathrm{Au}$ wires have a low hardness of approximately $216 \mathrm{MPa}$ $(\mathrm{Hv})$, which provides the benefits of superior processability and bonding properties by rapidly forming an intermetallic compound (IMC) with an Al pad. Although bonding wires of alternative materials are being developed due to high prices, $\mathrm{Cu}-\mathrm{Pd}$ wires appear to have the highest usage as $\mathrm{Au}$ accounts for $16 \%$ and $\mathrm{Cu}-\mathrm{Pd}$ accounts for $45 \%$ among the wire materials with high usages as of 2017. In Cu-Pd wires, the high corrosiveness of $\mathrm{Cu}$ wires is mitigated by a palladium coating, but the inherently high oxidation property of $\mathrm{Cu}$ cannot be completely prevented by the Pd coating. Furthermore, $\mathrm{Cu}$ is high in hardness at approximately $369 \mathrm{MPa}(\mathrm{Hv})$ and has the disadvantages of poor processability and bonding properties compared to $\mathrm{Au}$ and $\mathrm{Ag}$ wires since 
the formation rate of the intermetallic compound with an $\mathrm{Al}$ pad is low. On the other hand, Ag wires are similar in hardness to $\mathrm{Au}$ wires at $250 \mathrm{MPa}(\mathrm{Hv})$ and have excellent electrical conductivity, thermal conductivity, and corrosion resistance, serving as a new alternative to $\mathrm{Au}^{1-6)}$

The wire bonding methods largely include ball bonding and wedge bonding. In ball bonding, an arc is generated at the tip of a wire to form a free air ball (FAB), which is then bonded using ultrasonic waves. Wedge bonding is primarily a method of bonding Al wires by applying ultrasonic waves with a tool called a wedge. $\mathrm{Au}$ wires are typically used in ball bonding while Al, $\mathrm{Cu}$, and $\mathrm{Au}$ wires are used in wedge bonding ${ }^{6}$.

In this study, three types of wires were used in total, including two types of $\mathrm{Ag}$ wires and one type of $\mathrm{Au}$ wires. Modules were prepared by applying wire ball bonding to dummy modules consisting of a silicon chip bonded to a bismaleimide triazine (BT) printed circuit board (PCB). The ultrasonic bonding characteristics of each bonding wire material were compared by conducting a highly accelerated stress test (HAST) on the prepared modules and analyzing the bonding strength and microstructure before and after the test.

\section{Experimental Method}

\subsection{Wire Bonding}

BT PCBs with an Au-plated Ni pad were used as substrates in the experiment, and $\mathrm{Si}$ chips with an $\mathrm{Al}$ pad on the top were used as dummy chips. $97.3 \% \mathrm{Ag}$ wires, Au-coated 97.3\% Ag (ACA) wires, and 99.99\% Au wires were chosen as bonding wires, and their bonding characteristics were compared. Fig. 1 shows the process schematic. The diameter of all wires was $20.3 \mu \mathrm{m}$ ( $0.8 \mathrm{mil})$, and the bonding conditions were as shown in Table 1. After wire bonding, the surface and cross-sectional microstructures were analyzed through scanning electron microscope (SEM) analysis, and the initial bonding characteristics were compared by measuring the bonding strength.

\subsection{HAST Test}

The HAST test was conducted on the wire bonding modules to examine the characteristics of corrosion and degradation caused by high temperature and moisture permeation. To eliminate residual moisture inside the modules prior to the test, the modules were baked in an oven at $175^{\circ} \mathrm{C}$ for $6 \mathrm{~h}$ and in an HAST chamber (PC-R8D(HIRAYAMA)) at $130^{\circ} \mathrm{C} / 85 \% \mathrm{RH}$ for $168 \mathrm{~h}$. After the test, the bonding strength of the bonding wires was measured and compared to the initial characteristics, and SEM analysis was conducted to analyze micro defects after pre-treating the cross-section of the bonding interface using a focused ion beam (FIB) device.

\subsection{Bonding Strength Test}

A bonding test machine (Dage 4000, Nordson Co. Ltd., USA) device was used for the bonding strength test, and the wire ball shear test (BST) and the wire ball pull test were conducted. Fig. 2 shows the test directions and photographs. The ball shear test was performed at a test rate of $500 \mu \mathrm{m} / \mathrm{s}$ and a test height of 2.5

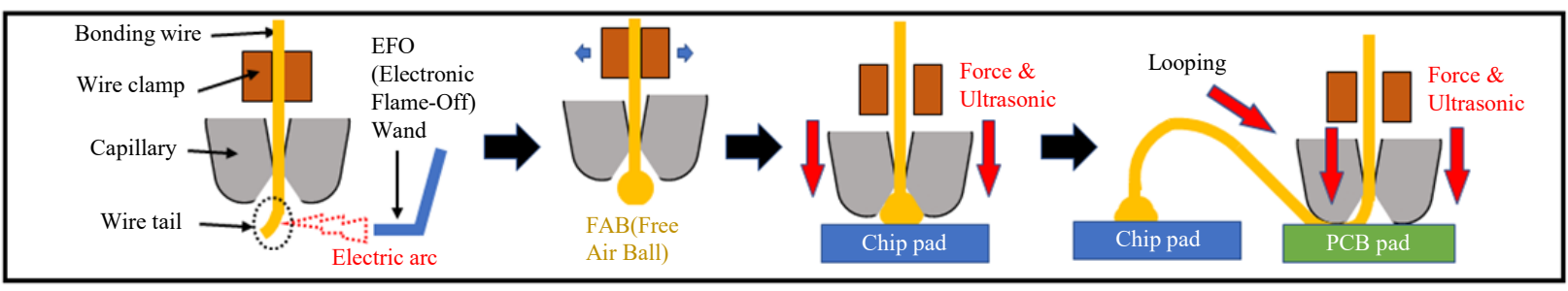

Fig. 1 Schematic explanation of wire ball bonding process

Table 1 Wire bonding conditions

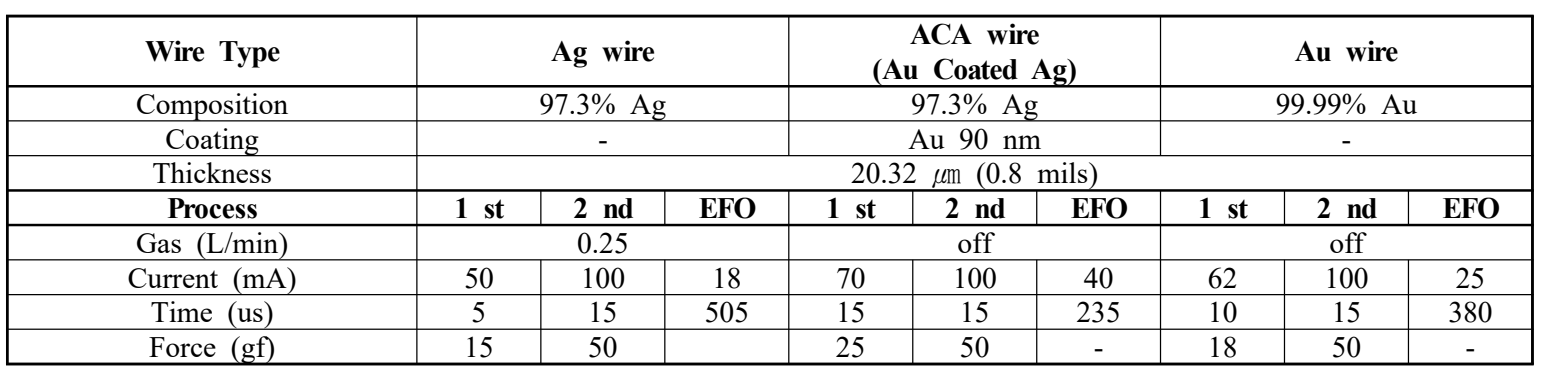



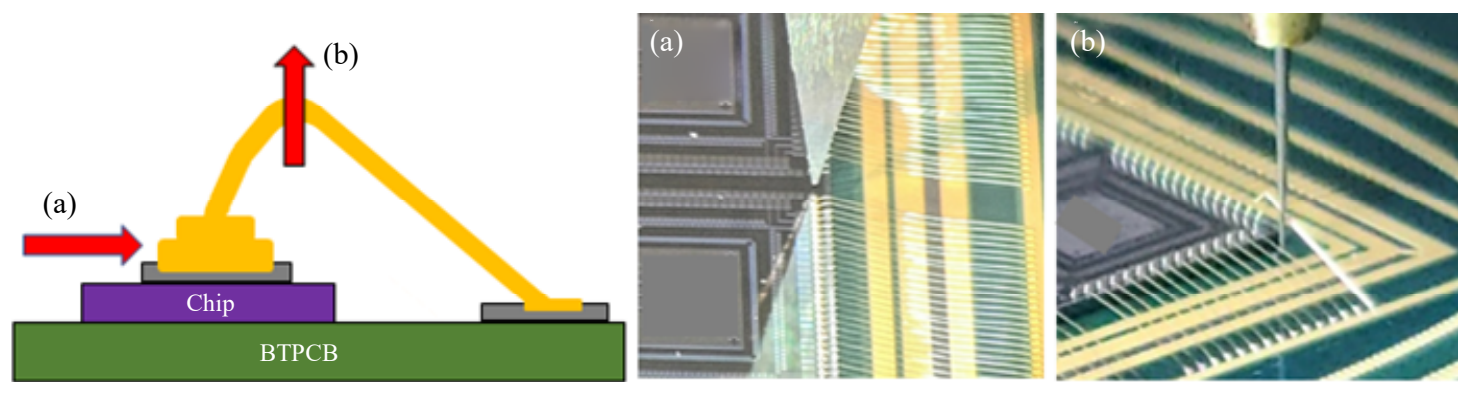

Fig. 2 Schematic and optical micrograps of bonding strength measurement, (a) wire ball shear test and (b) wire ball pull test

$\mu \mathrm{m}$, and the wire pull test was performed at a test rate of $1,000 \mu \mathrm{m} / \mathrm{s}$. The bonding wires were examined before and after the HAST test to compare the bonding strength characteristics depending on the wire alloy.

\section{Experimental Results}

\subsection{Initial Bonding Characteristics of Bonding Wires}

After wire bonding, the appearance and cross-sectional SEM analysis confirmed adequate bonding (Fig. $3,4)$, and the initial BST measurement produced similar results between the $\mathrm{Au}$ wire at $23.37 \mathrm{gf}, \mathrm{Ag}$ wire at
24.40 gf, and ACA wire at 23.43 gf (Fig. 5). The BPT test results indicated that the ACA wire had the highest tensile strength with the $\mathrm{Au}$ wire at $3.11 \mathrm{gf}, \mathrm{Ag}$ wire at $4.25 \mathrm{gf}$, and ACA wire at $5.96 \mathrm{gf}$ (Fig. 6).

\subsection{Bonding Characteristics After HAST Test}

Fig. 5 and Fig. 6 show the bonding strength measurements of the Ag wire following the HAST test. The bonding strength measured after the test was $6.12 \mathrm{gf}$, about $75 \%$ lower than the initial value. On the other hand, the bonding strength of the ACA wire was about $47 \%$ lower at $12.54 \mathrm{gf}$, confirming that its bonding strength was better than that of the Ag wire.

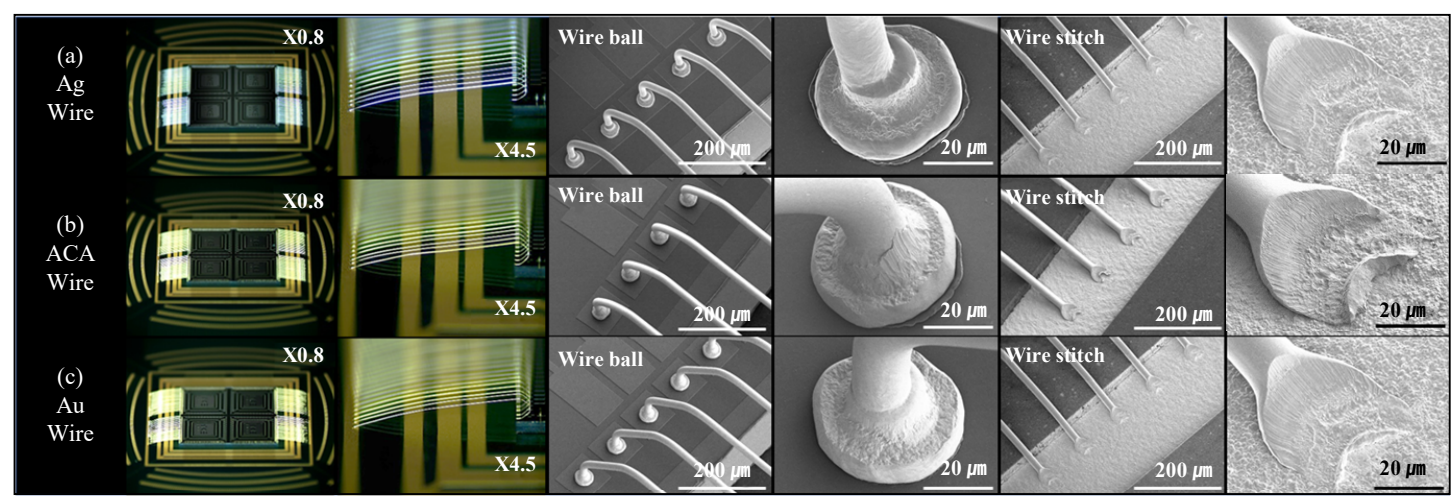

Fig. 3 Optical and SEM micrographs of wire bonding modules, (a) Ag wire, (b) Au coated Ag wire (ACA) and (c) Au wire

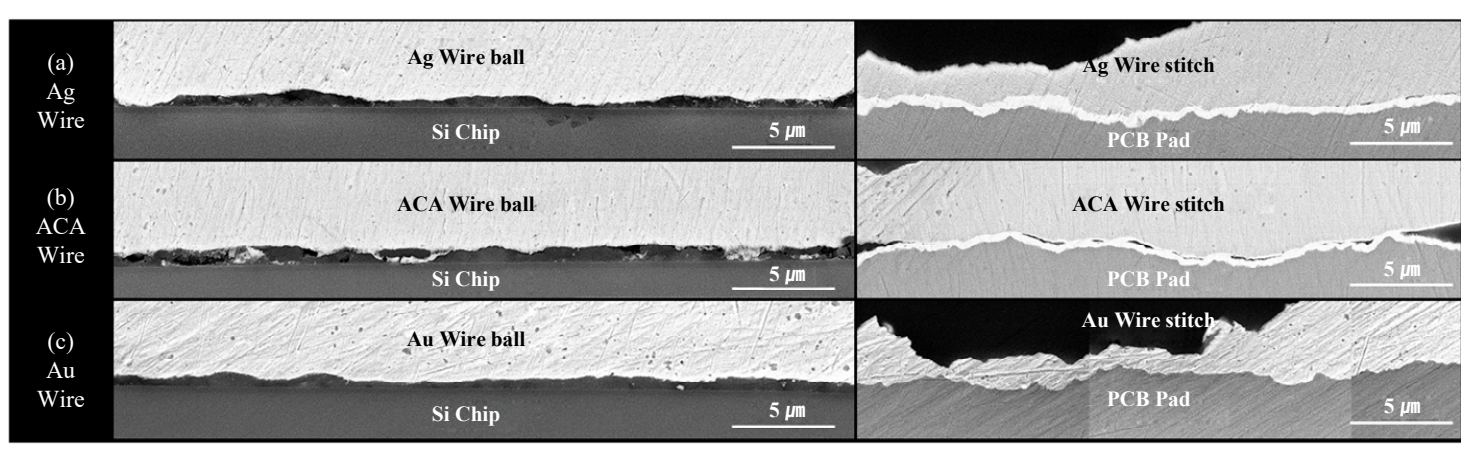

Fig. 4 Cross-sectional SEM micrographs of ultrasonic bonding interfaces of wire bonding modules, (a) Ag wire, (b) Au coated Ag wire (ACA) and (c) Au wire 


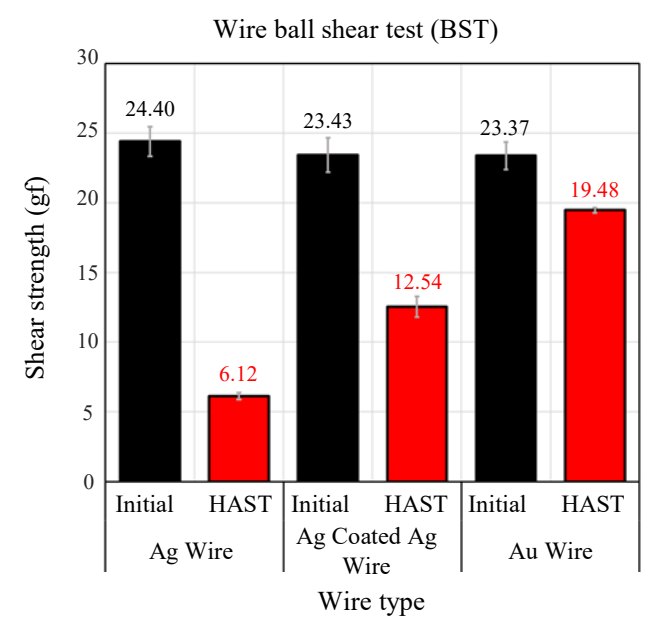

Fig. 5 Bonding strength comparison with before and after reliability test: wire ball shear test

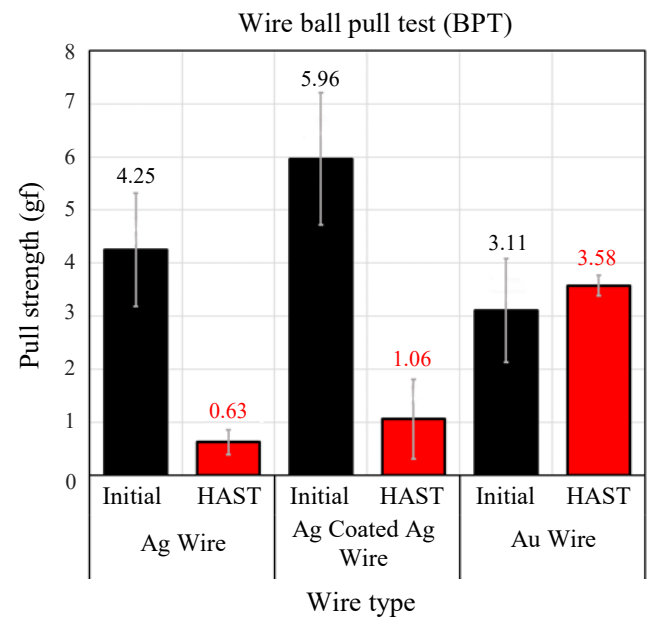

Fig. 6 Bonding strength comparison with before and after reliability test: wire ball pull test

As shown in Fig. 7, the cross-sectional microstructure analysis of the bonding wire interfaces indicated a thick $\mathrm{Au}-\mathrm{Al}$ intermetallic compound (IMC) layer with a high $\mathrm{Au}$ content, as well as micro cracks at the end of the bonding interface. On the bonding interface of the ACA wire, a thin Ag-Au-Al intermetallic compound layer was observed, and a crack was found to propagate from the end of the bonding interface to around the intermetallic compound layer (Fig. 7). Since spherical free air balls are bonded under pressure in the wire ball method, the bonding interface is most vulnerable at its two ends. This explains why the cracks occurred at both ends of the bonding interface, while the intermetallic compound layer formed within the bonding interface appeared to prevent the cracks from propagating further. On the other hand, a very long crack occurred in the bonding interface of the $\mathrm{Ag}$ wire, accounting for $69 \%$ of the bonding interface, and progressed along the finely formed intermetallic compound layer.

A previous study by Jaafar and Tseng showed that, among $\mathrm{Au}, \mathrm{Ag}$, and $\mathrm{Cu}$ wires, $\mathrm{Au}$ wires had the highest reactivity with an $\mathrm{Al}$ pad, resulting in the fastest formation of an intermetallic coumpound ${ }^{5)}$. It was also reported that $\mathrm{ACA}$ wires formed an $\mathrm{AuAl}_{2}$ intermetallic compound at the top and an Ag-Al-Au intermetallic compound at the bottom after the wires were stored at a high temperature of $175^{\circ} \mathrm{C}$ for 500 hours ${ }^{7)}$. Despite a low $\mathrm{Au}$ content, ACA wires reacted with the Al pad first, forming an $\mathrm{Au}-\mathrm{Al}$ intermetallic compound. Although an $\mathrm{Au}-\mathrm{Al}$ intermetallic compound is generally known to cause cracks in the bonding interface of $\mathrm{Au}$ wires, according to the study, the strength of $\mathrm{AuAl}_{2}$ in the $\mathrm{Au}-\mathrm{Al}$ intermetallic compound is brittle and vulnerable at the bonding interface, while intermetallic compounds such as $\mathrm{Au}_{2} \mathrm{Al}$ and $\mathrm{Au}_{4} \mathrm{Al}$ with a higher $\mathrm{Au}$ content (or a relatively lower $\mathrm{Al}$ content) are ductile and more resistant to crack propagation ${ }^{8)}$. In this study, an Au-Al intermetallic compound layer with a high $\mathrm{Au}$ content was also observed, which is believed to have prevented the crack from propagating.

Kirkendall voids, which are also problematic along with the intermetallic compound at the bonding interface of $\mathrm{Au}$ wires, reduce the bonding reliability due to the initiation and propagation of cracks. Au alloy wires can be used to prevent Kirkendall voids, and some studies have reported that Kirkendall voids do not occur in Au-15\% Ag-5 \% Pd alloy wires even after storing them at a high temperature of $180^{\circ} \mathrm{C}$ for 1500 hours ${ }^{9}$. Kirkendall voids are created as a result of the difference in the interdiffusion rate of $\mathrm{Au}$ and $\mathrm{Al}$ and the difference in the volume of the formed IMC during the formation process of the $\mathrm{Au}-\mathrm{Al}$ intermetallic compound. In the Au-Ag-Pd alloy wire, an Au-Ag-Al layer is formed below an Au-al layer, reducing the interdiffusion reaction of Au-Al. In this study, about five Kirkendall voids were found at the bonding interface of the $\mathrm{Au}$ wire, while about one Kirkendall void was observed at the bonding interface of the ACA wire with an AuAg-Al layer, indicating that the Ag content was effective in preventing Kirkendall voids.

\section{Conclusions}

In this study, $20.32 \mu \mathrm{m}$ (0.8 mil) wires in $97.3 \% \mathrm{Ag}$, Au-coated $97.3 \%$ Ag(ACA), and $99.99 \%$ Au materials were used to prepare dummy packages through ball bonding and stitch bonding. BST and BPT were measured before and after the HAST test conducted at $130^{\circ} \mathrm{C}$ and $85 \% \mathrm{RH}$, and the changes in the microstructure characteristics of the ultrasonic bonding interface of the wires were compared. 


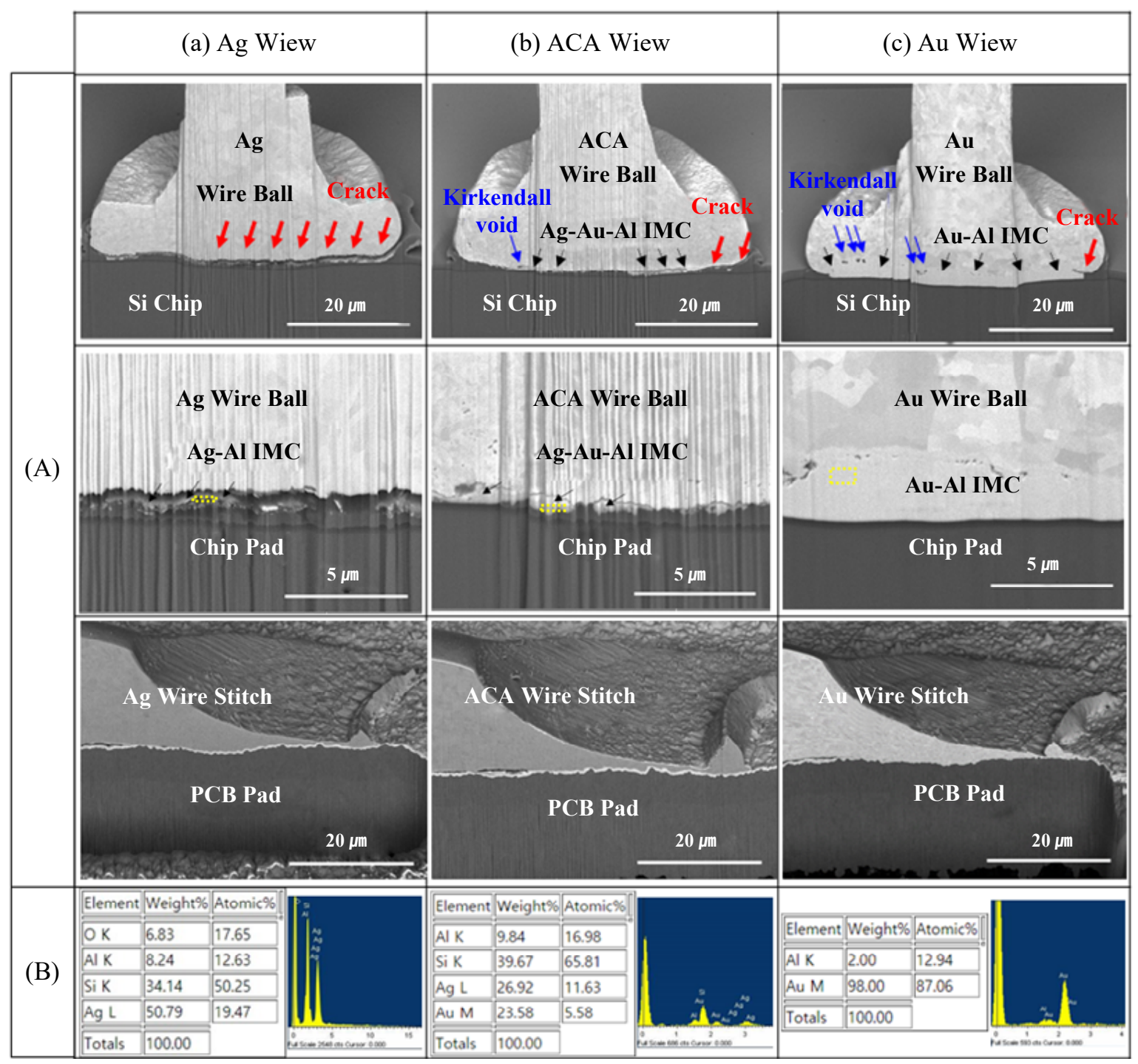

Fig. 7 FIB cross-sectional (A) SEM micrographs and (B) EDS analysis results after reliability test, (a) Ag wire, (b) Au coated Ag wire (ACA) and (c) Au wire

1) The BST results showed that the initial bonding strength was similar at about 23-24 gf, but the bonding strength of the Ag, ACA, and Au wires decreased by about $75 \%, 47 \%$, and $17 \%$, respectively, after the HAST test.

2) In the microstructure analysis, cracks were found to occur and propagate from the ends of the bonding interface, while the $\mathrm{Au}-\mathrm{Al}$ intermetallic compound at the bonding interface of the ACA and Au wires with a high $\mathrm{Au}$ content was thought to have prevented the cracks from propagating.

3) Kirkendall voids were observed at the bonding interface of the Au wire, while almost none was found at the bonding interface of the ACA wire. It is believed that the Ag-Au-Al intermetallic compound formed at the bonding interface of the ACA wire acted as an obstacle to the $\mathrm{Au}-\mathrm{Al}$ interdiffusion reaction, reducing the formation of Kirkendall voids.

\section{Acknowledgements}

This work was supported by the Technology Innovation Program - Materials and Components Development Program (Grant No. 20011427) funded by the Korean Ministry of Trade, Industry, and Energy (MOTIE) in the Republic Korea.

ORCID: Mi-Song Kim: https://orcid.org/0000-0002-4717-9365 ORCID: Won Sik Hong: http://orcid.org/0000-0001-8398-177X ORCID: Sang Yeop Kim: https://orcid.org/0000-0001-7371-5718 ORCID: Sung Min Jeon: https://orcid.org/0000-0001-6685-8796

\section{References}

1. J. P. Jung, Ultrasonic Bonding of Electronic Parts, 
Proceedings of the 2008 Autumn Meeting of KWJS, Incheon (2008) 7-9.

2. J. Y. Park, C. M. Oh, D. H. Won, and W. S. Hong, Ultrasonic Bonding Property of Aluminium Wire for Power Conversion Module of Automotive, J. Weld. Join., 36(3) (2018) 57-64. https://doi.org/10.5781/JWJ.2018.36.3.9

3. M. Schneider-Ramelow, C. Ehrhardt, The reliability of wire bonding using $\mathrm{Ag}$ and Al, J. Microelectron. Reliab. 63 (2016) 336-341. http://dx.doi.org/10.1016/j.microrel.2016.05.009

4. P. Lall, S. Deshpande, and L. Nguyen, Reliability of Copper, Gold, Silver, and PCC Wirebonds Subjected to Harsh Environment, Proceedings of Electronic Components and Technology Conference (ECTC), IEEE 68th (2018) 724-734.

https://doi.org/10.1109/ECTC.2018.00113

5. N. B. Jaafar and E. W. L. Ching, Comparison of Au/Al, $\mathrm{Cu} / \mathrm{Al}$ and $\mathrm{Ag} / \mathrm{Al}$ in Wirebonding Assembly and IMC Growth Behavior, Proceedings of Electronics Packaging Technology Conference (EPTC), IEEE 18th (2016) 10-12. https://doi.org/10.1109/EPTC.2016.7861432
6. J. M. Kim, J. P. Jung, S. H. Kim, and J. H. Pack, Packaging Technology in Electronics and 3-dimensional Stacking Packaging, J. Korean Weld. Join Soc., 23(2) (2005) 23-31.

7. Y. W. Tseng, F. Y. Hung, and T. S. Lui, Wire bonding of $\mathrm{Au}$-coated Ag wire, bondwire properties, bondability and IMCs formation, Proceedings of European Microelectronics Packaging Conference (2015) 1-4.

8. H. Yang, K. Cao, X. T. Zhao, W. Liu, J. Lu, and Y. Lu, Brittle-to-ductile transition of $\mathrm{Au} 2 \mathrm{Al}$ and $\mathrm{AuAl}_{2}$ intermetallic compounds in wire bonding, J. Mater. Sci.: Mater. Electron. 30 (2019) 862-866. https://doi.org/10.1007/s10854-018-0357-6

9. H. Liu, Q. Chen, Z. Zhao, Q. Wang, J. Zeng, J. H. Chae, and J. S. Lee, Reliability of Au-Ag Alloy Wire Bonding, Proceedings of Electronic Components and Technology Conference(ECTC), IEEE 60th (2010) 234239.

https://doi.org/10.1109/ECTC.2010.5490906 


\title{
반도체 패키징용 금 코팅된 은 와이어의 초음파 접합부 열화 특성
}

\author{
Ultrasonic Bonding Interface Degradation Characteristics \\ of Gold-Coated Silver Wire for Semiconductor Packaging
}

\author{
김미송* · 홍원식 ${ }^{*}$ 김상엽 ${ }^{* *} \cdot$ 전성민 ${ }^{* *} \cdot$ 문정탁** \\ "한국전자기술연구원 융복합전자소재연구센터 \\ **엠케이전자(주) 기술연구소 재료개발팀
}

1. 서 론

본딩 와이어(Bonding wire)는 반도체 직접회로(Integrated circuit), RF(Radio frequency), FPGA(Field programmable gate array), LED(Light emitting diode) 및 메모리 패키지(Memory Package) 등 다 양한 반도체 소자의 신호를 전달하는 역할을 한다. 반 도체 모듈의 효율 및 신뢰성에 직접적인 영향을 미칠 수 있으므로 내부식성과 접합부의 열화 특성이 우수한 소재의 본딩 와이어를 선정하는 것이 중요하다. 본당 와이어 소재로는 금 $(\mathrm{Au})$, 은 $(\mathrm{Ag})$, 알루미늄 $(\mathrm{Al})$, 구리 $(\mathrm{Cu})$, 팔라듐 코팅된 구리 $(\mathrm{Pd}-$ coated $\mathrm{Cu})$, 팔라듐 도 핑된 구리 $(\mathrm{Pd}-$ doped $\mathrm{Cu})$, 금 코팅된 구리 $(\mathrm{Au}-$ coated $\mathrm{Cu}$ ) 등이 있으며, 내부식성이 가장 좋은 $\mathrm{Au}$ 와이어가 주로 사용되어왔다. $\mathrm{Au}$ 와이어는 내부식성뿐만 아니라 약 $216 \mathrm{MPa}\left(\mathrm{HV}_{\mathrm{V}}\right)$ 의 낮은 경도 특성으로 와이어 공정 성과 $\mathrm{Al}$ 패드와의 금속간화합물(Intermetallic $\mathrm{com}^{-}$ pound, IMC)을 빠르게 형성하여 접합 특성이 우수한 장점이 있다. 하지만 높은 가격으로 인해 대체 소재의 본딩 와이어가 개발되고 있으며, 현재 사용 비중이 높은 와이어는 2020 년 기준 $\mathrm{Au} 30 \%, \mathrm{Cu}-\mathrm{Pd} 45 \%, \mathrm{Cu}$ $15 \%$, 기타 $10 \%, \mathrm{Cu}-\mathrm{Pd} 45 \%$ 로 $\mathrm{Cu}-\mathrm{Pd}$ 와이어의 비중이 매우 높은 것을 알 수 있다. $\mathrm{Cu}-\mathrm{Pd}$ 와이어는 $\mathrm{Cu}$ 와이어의 높은 부식성을 팔라듐 코팅으로 완화하였 지만, $\mathrm{Cu}$ 고유의 높은 산화 특성을 $\mathrm{Pd}$ 코팅으로 완전 히 방지할 수 없는 문제점이 있다. 또한, $\mathrm{Cu}$ 는 약 $369 \mathrm{MPa}(\mathrm{HV})$ 의 높은 경도 특성으로 공정성이 떨어 지고 $\mathrm{Al}$ 패드와의 금속간화합물 형성 속도가 느려서 $\mathrm{Au}, \mathrm{Ag}$ 와이어에 비해 접합 특성이 좋지 않은 단점이 있다. 반면, $\mathrm{Ag}$ 와이어는 약 $250 \mathrm{MPa}(\mathrm{HV})$ 의 경도 특성으로 $\mathrm{Au}$ 와 비슷한 수준이며, 전기 및 열 전도성, 내부식성이 우수한 장점이 있어서 새로운 $\mathrm{Au}$ 대체 소 재로 적용되고 있다 ${ }^{1-6)}$.
와이어 본딩 방법은 크게 볼 본딩(Ball bonding)과 웨지 본딩(Wedge bonding)이 있다. 볼 본딩은 와이 어 끝에 아크(Arc)를 발생시켜 프리 에어 볼(Free air ball, $\mathrm{FAB}$ )을 형성시킨 후 초음파를 이용하여 접합한 다. 웨지 본딩은 주로 $\mathrm{Al}$ 와이어를 웨지라는 툴로 초음 파를 가하여 접합하는 방식이다. 주로 볼 본딩은 $\mathrm{Au}, \mathrm{Cu}$ 와이어, 웨지 본딩은 $\mathrm{Al}, \mathrm{Cu}$ 와이어를 사용한다).

본 연구에서는 $\mathrm{Ag}$ 와이어 2 종, $\mathrm{Au}$ 와이어 1 종의 총 3 종의 와이어를 사용하였고, BT(Bismaleimide triazine) $\mathrm{PCB}$ (Printed circuit board)에 실리콘 칩이 접 합된 더미 모듈(Dummy module)에 와이어 볼 본딩을 적용한 모듈을 제작하였다. 제작된 모듈은 HAST (Highly accelerated stress test) 시험을 진행하여 시험 전/ 후 와이어의 접합강도 및 미세조직을 분석을 통해 본딩 와이어의 소재별 초음파 접합 특성을 비교하였다.

\section{2. 실험 방법}

\section{1 와이어 본딩}

실험에 사용된 기판은 $\mathrm{Au}$ 도금된 $\mathrm{Ni}$ 패드가 적용된 $\mathrm{BT}$ PCB를 사용하였고, Dummy Chip은 상부에 $\mathrm{Al}$ 패드가 적용된 $\mathrm{Si}$ 칩을 사용하였다. 본딩 와이어는 $97.3 \% \mathrm{Ag}$ 와이어, $\mathrm{Au}$ 코팅된 $97.3 \% \mathrm{Ag}(\mathrm{Au}$ coated $97.3 \% \mathrm{Ag}, \mathrm{ACA})$ 와이어, $99.99 \% \mathrm{Au}$ 와이어를 선정하여 접합 특성을 비교하였다. 공정 모식도는 Fig. 1 에 나타내었다. 각 와이어의 직경은 모두 $20.32 \mu \mathrm{m}$ (0.8 mil)이었고, 본딩 조건은 Table 1과 같았다. 와 이어 본딩 후 SEM(Scanning electron microscope) 분석을 이용하여 표면 및 단면 미세조직을 분석하였고, 접합강도를 측정하여 초기 접합 특성을 비교하였다.

\subsection{HAST 시험}

와이어 본딩 모듈은 고온 및 수분 투습에 따른 부식 


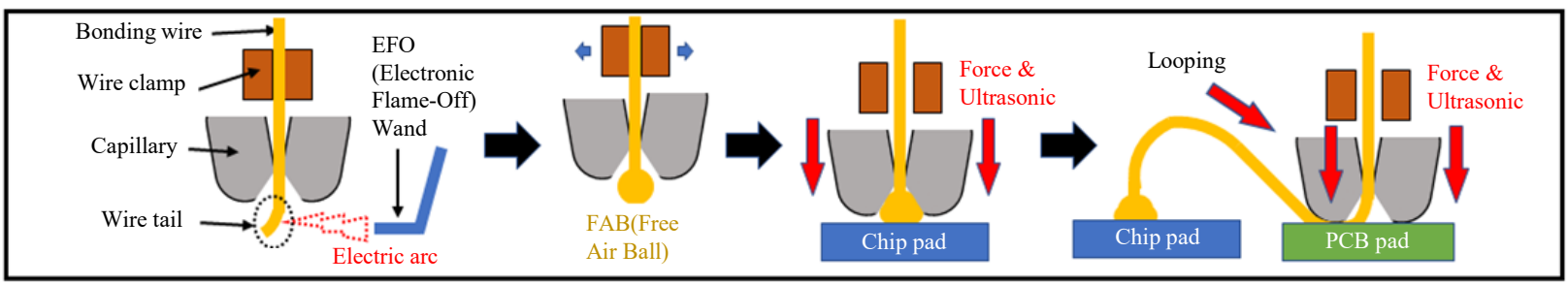

Fig. 1 Schematic explanation of wire ball bonding process

Table 1 Wire bonding conditions

\begin{tabular}{|c|c|c|c|c|c|c|c|c|c|}
\hline Wire Type & \multicolumn{3}{|c|}{ Ag wire } & \multicolumn{3}{|c|}{$\begin{array}{c}\text { ACA wire } \\
(\text { Au Coated Ag) }\end{array}$} & \multicolumn{3}{|c|}{ Au wire } \\
\hline Composition & \multicolumn{3}{|c|}{$97.3 \% \mathrm{Ag}$} & \multicolumn{3}{|c|}{$97.3 \% \mathrm{Ag}$} & \multicolumn{3}{|c|}{$99.99 \% \mathrm{Au}$} \\
\hline Coating & \multicolumn{3}{|c|}{-} & \multicolumn{3}{|c|}{$\mathrm{Au} 90 \mathrm{~nm}$} & \multicolumn{3}{|c|}{-} \\
\hline Thickness & \multicolumn{9}{|c|}{$20.32 \mu \mathrm{m}(0.8 \mathrm{mils})$} \\
\hline Process & 1 st & 2 nd & EFO & $1 \mathrm{st}$ & 2 nd & EFO & 1 st & $2 \mathrm{nd}$ & EFO \\
\hline Gas (L/min) & \multicolumn{3}{|c|}{0.25} & \multicolumn{3}{|c|}{ off } & & off & 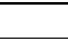 \\
\hline Current (mA) & 50 & 100 & 18 & 70 & 100 & 40 & 62 & 100 & 25 \\
\hline Time (us) & 5 & 15 & 505 & 15 & 15 & 235 & 10 & 15 & 380 \\
\hline Force (gf) & 15 & 50 & & 25 & 50 & - & 18 & 50 & - \\
\hline
\end{tabular}
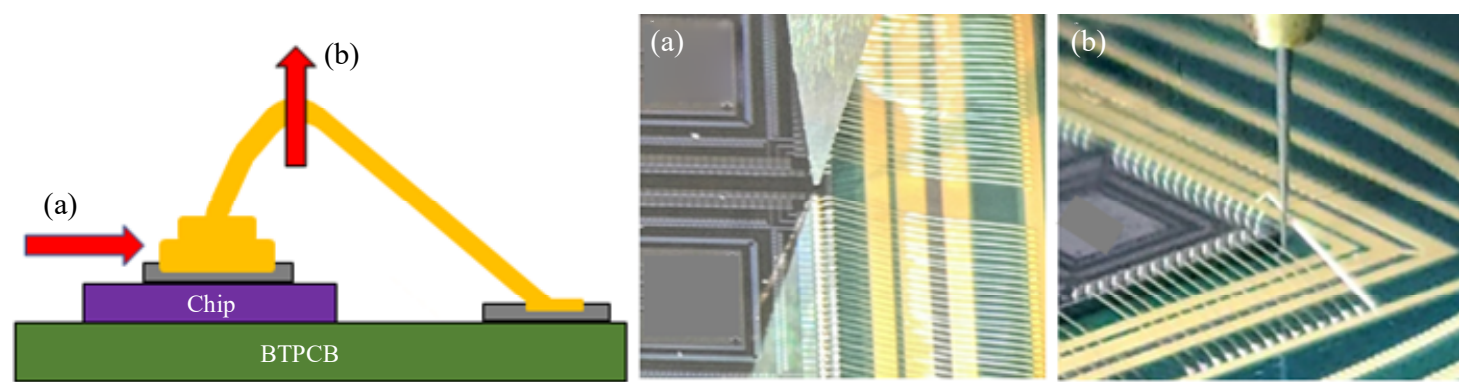

Fig. 2 Schematic and optical micrograps of bonding strength measurement, (a) wire ball shear test and (b) wire ball pull test

및 열화 특성을 관찰하기 위해 $\mathrm{HAST}$ 시험을 진행하였 다. 시험 전 모듈 내부 잔존 수분을 제거하기 위해 $175^{\circ} \mathrm{C}$ 오븐(Oven)에서 $6 \mathrm{~h}$ 방치 후 $\mathrm{HAST}$ 챔버( $\mathrm{PC}-$ $\mathrm{R} 8 \mathrm{D}$ (HIRAYAMA))를 이용하여 $130^{\circ} \mathrm{C} / 85 \% \mathrm{RH}$ 조 건으로 $168 \mathrm{~h}$ 진행하였다. 시험 후 본딩 와이어의 접합 강도를 측정하여 초기 특성과 비교하였고, 미세 결함을 분석하기 위해 FIB(Focused ion beam) 장비를 이용 하여 접합부 단면 전처리 후 $\mathrm{SEM}$ 분석을 진행하였다.

\section{3 접합강도 시험}

접합강도 시험은 Dage4000(Nordson Co. Ltd.) 장 비를 이용하였고, 와이어 볼 전단시험(Ball shear test, $\mathrm{BST}$ )과 와이어 볼 풀 시험(Wire ball pull test, $\mathrm{BPT}$ ) 를 진행하였다. 시험 방향 및 사진은 그림과 같았다. 볼 전단시험은 시험 속도 $500 \mu \mathrm{m} / \mathrm{sec}$, 시험 높이 $2.5 \mu \mathrm{m}$ 조건 으로 진행했고, 와이어 풀 시험은 시험 속도 $1,000 \mu \mathrm{m} / \mathrm{sec}$ 로 진행하였다. 초기 및 $\mathrm{HAST}$ 시험 후 본딩 와이어를
모두 측정하여 와이어 합금에 따른 접합강도 특성을 비 교하였다.

\section{3. 실험 결과}

\section{1 본딩 와이어 초기 접합 특성}

와이어 본딩 후 외관 및 단면 $\mathrm{SEM}$ 분석을 통해 접 합이 잘 된 것을 확인하였고(Fig. 3,4 ), 초기 $\mathrm{BST}$ 측정 결과 $\mathrm{Au}$ 와이어 $23.37 \mathrm{gf}, \mathrm{Ag}$ 와이어 $24.40 \mathrm{gf}$, $\mathrm{ACA}$ 와이어 $23.43 \mathrm{gf}$ 로 비슷한 것을 알 수 있었다 (Fig. 5). BPT 시험 결과는 $\mathrm{Au}$ 와이어 $3.11 \mathrm{gf}, \mathrm{Ag}$ 와이어 $4.25 \mathrm{gf}, \mathrm{ACA}$ 와이어 $5.96 \mathrm{gf}$ 로 $\mathrm{ACA}$ 와이 어의 인장강도가 가장 높은 것을 알 수 있었다(Fig. 6).

\section{$3.2 \mathrm{HAST}$ 시험 후 접합 특성}

$\mathrm{HAST}$ 시험 후 $\mathrm{Ag}$ 와이어의 접합강도 측정결과를 Fig. 5와 Fig. 6에 나타내었다. 시험 후 측정된 접합 


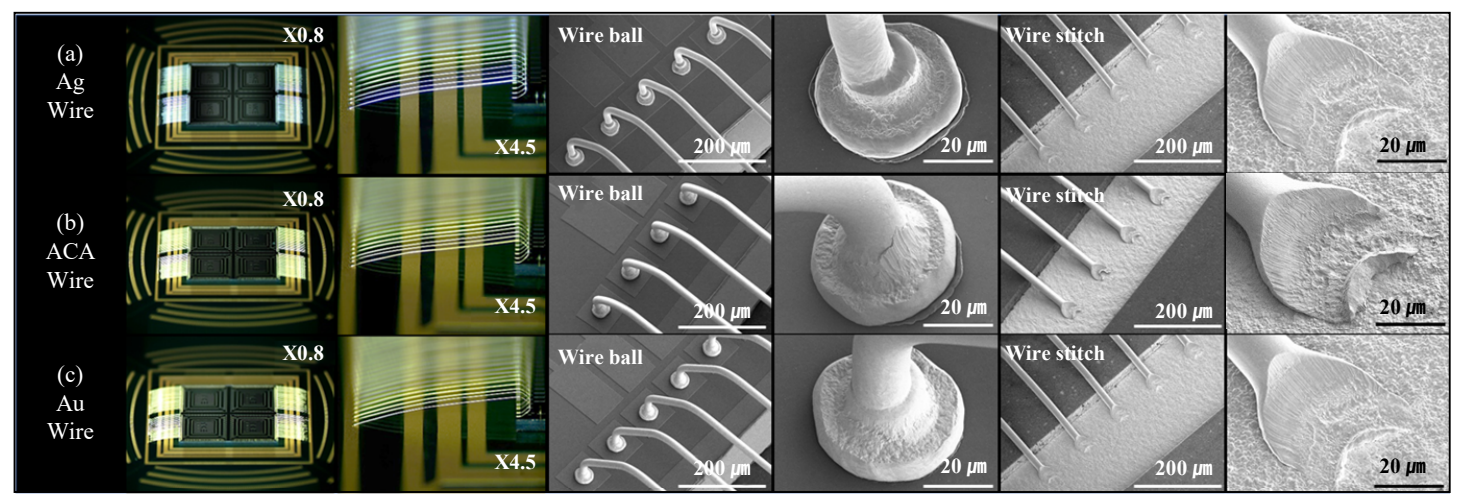

Fig. 3 Optical and SEM micrographs of wire bonding modules, (a) Ag wire, (b) Au coated Ag wire (ACA) and (c) Au wire

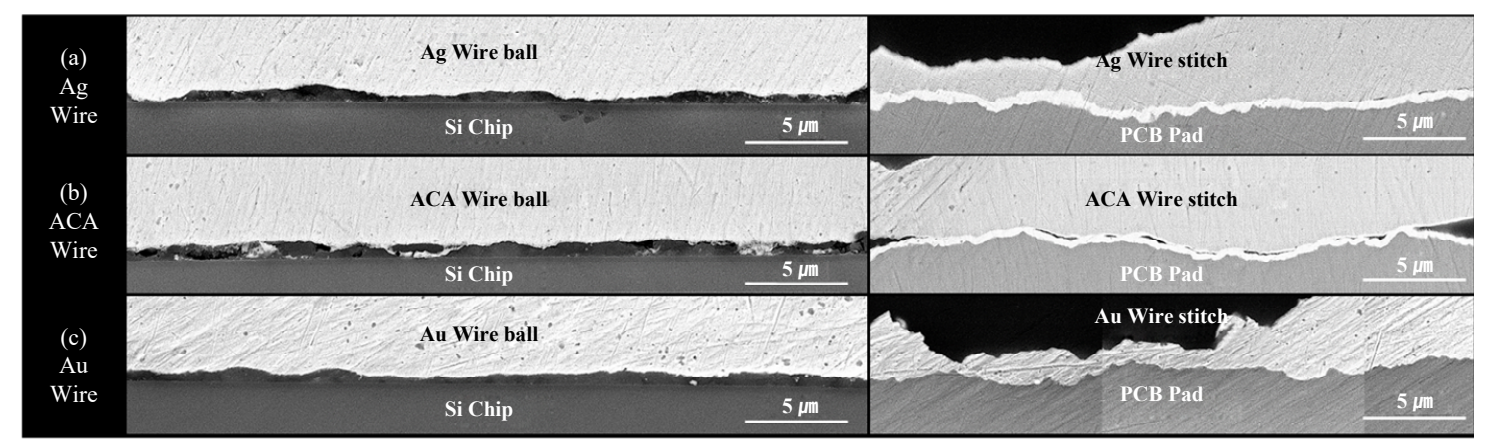

Fig. 4 Cross-sectional SEM micrographs of ultrasonic bonding interfaces of wire bonding modules, (a) Ag wire, (b) Au coated Ag wire (ACA) and (c) Au wire

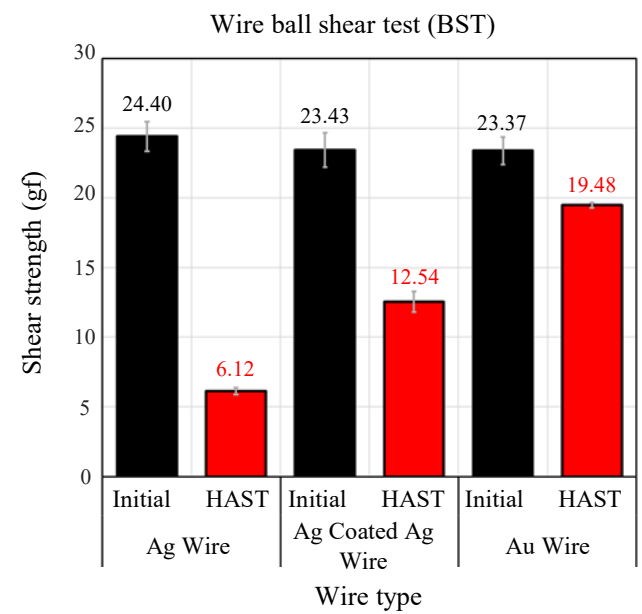

Fig. 5 Bonding strength comparison with before and after reliability test: wire ball shear test

강도는 $6.12 \mathrm{gf}$ 로 초기 대비 약 $75 \%$ 감소된 것을 알 수 있었다. 반면 $\mathrm{ACA}$ 와이어의 접합강도는 $12.54 \mathrm{gf}$ 로 약 $47 \%$ 감소되어 $\mathrm{Ag}$ 와이어보다 접합 특성이 우 수한 것을 알 수 있었다.

Fig. 7과 같이 본딩 와이어 접합부 단면 미세조직 분석결과, $\mathrm{Au}$ 와이어 접합부에서 $\mathrm{Au}$ 함량이 많은 $\mathrm{Au}^{-}$

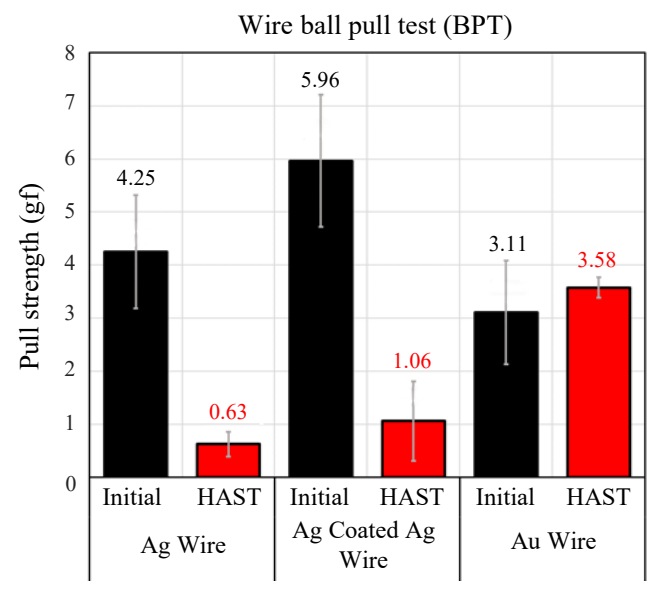

Wire type

Fig. 6 Bonding strength comparison with before and after reliability test: wire ball pull test

$\mathrm{Al}$ 금속간화합물(Intermetallic compound, IMC) 층 이 두껍게 관찰되었고, 접합부 끝에 미세한 균열이 관찰 되었다. $\mathrm{ACA}$ 와이어 접합부에서는 얇은 $\mathrm{Ag}-\mathrm{Au}-\mathrm{Al}$ 금속간화합물 층이 관찰되었고, 접합부 끝부터 발생한 균열이 금속간화합물 층 직전까지 전파된 것을 관찰할 수 있었다(Fig. 7). 와이어 볼은 구 형태의 프리 에어 


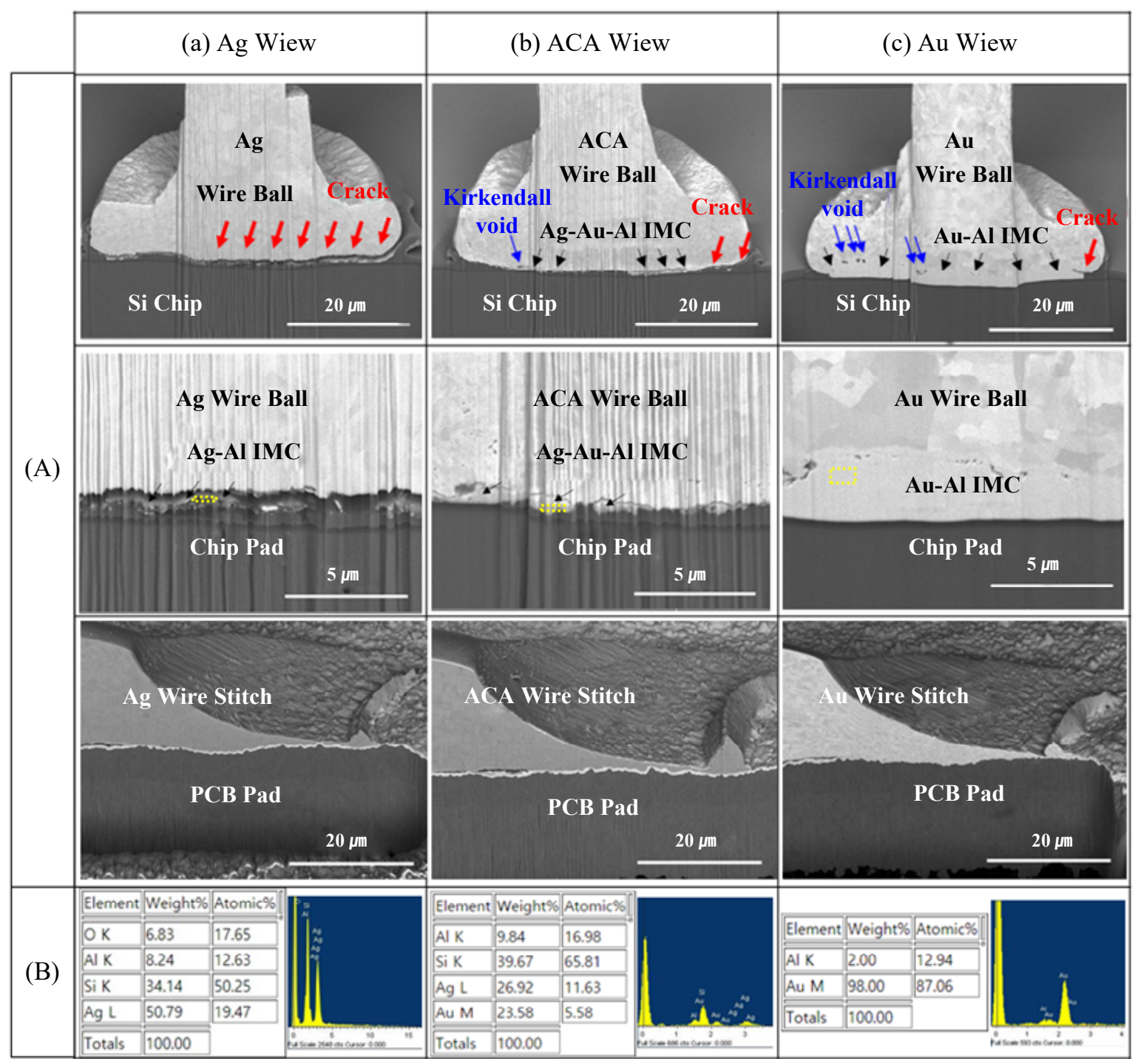

Fig. 7 FIB cross-sectional (A) SEM micrographs and (B) EDS analysis results after reliability test, (a) Ag wire, (b) Au coated Ag wire (ACA) and (c) Au wire

볼을 가압 접합하는 방식이므로 양 끝의 접합부가 가장 취약하다. 따라서 균열이 접합부 양 끝부분에서 발생한 것으로 보이며, 접합부 내에 형성된 금속간화합물 층이 균열의 전파를 억제하는 것으로 관찰되었다. 반면 $\mathrm{Ag}$ 와이어 접합부에서는 균열이 접합부의 $69 \%$ 로 매우 길 게 발생하였고, 미세하게 형성된 금속간화합물 층을 따 라 균열이 진전한 것을 알 수 있었다.

Jaafar와 Tseng의 선행연구 결과에 따르면 $\mathrm{Al}$ 패드 와의 반응성은 $\mathrm{Au}, \mathrm{Ag}, \mathrm{Cu}$ 와이어 중 $\mathrm{Au}$ 와이어가 가장 우수하여 금속간화합물이 가장 빠르게 형성되며5), $\mathrm{ACA}$ 와이어의 경우 $175^{\circ} \mathrm{C}$ 에서 $500 \mathrm{~h}$ 고온저장시험 이후 접합부 상부에서 $\mathrm{AuAl}_{2}$ 금속간화합물, 하부에 $\mathrm{Ag}-\mathrm{Al}-\mathrm{Au}$ 금속간화합물 층이 형성된 것으로 보고 되 었다 ${ }^{7)} \mathrm{ACA}$ 와이어에서 $\mathrm{Au}$ 함량은 매우 소량임에도 가장 먼저 $\mathrm{Al}$ 패드와 반응하여 $\mathrm{Au}-\mathrm{Al}$ 금속간화합물을
형성한 것을 알 수 있다. $\mathrm{Au}-\mathrm{Al}$ 금속간화합물은 일반 적으로 $\mathrm{Au}$ 와이어 접합부에서 균열을 초래하는 것으로 알려졌지만, 논문에 따르면 $\mathrm{Au}-\mathrm{Al}$ 금속간화합물에서 $\mathrm{AuAl}_{2}$ 는 강도는 강하지만 취성이기 때문에 접합부에 서 취약하며, $\mathrm{Au}$ 함량이 많은 $(\mathrm{Al}$ 함량이 상대적으로 적은) $\mathrm{Au}_{2} \mathrm{Al}$ 혹은 $\mathrm{Au}_{4} \mathrm{Al}$ 과 같은 금속간화합물은 연성 으로 균열 전파에 강하다고 한다 ${ }^{8)}$. 본 연구에서도 $\mathrm{Au}$ 함량이 많은 $\mathrm{Au}-\mathrm{Al}$ 금속간화합물 층이 관찰되었고, 효 과적으로 균열의 전파를 막아준 것으로 생각된다.

$\mathrm{Au}$ 와이어 접합부에서 금속간화합물과 함께 문제가 되는 커켄달 보이드(Kirkendall void)는 균열의 발생 과 전파로 신뢰성 저하의 원인이 된다. 커켄달 보이드 를 방지하는 방법으로 $\mathrm{Au}$ 합금 와이어를 적용할 수 있 으며, 연구에 따르면 $\mathrm{Au}-15 \% \mathrm{Ag}-5 \% \mathrm{Pd}$ 합금 와 이어의 경우 $180^{\circ} \mathrm{C}$ 에서 $1500 \mathrm{~h}$ 고온저장시험 이후에 
도 커켄달 보이드가 발생하지 않는 것으로 보고되었다 9). 커켄달 보이드는 $\mathrm{Au}-\mathrm{Al}$ 금속간화합물이 형성되는 과정에서 $\mathrm{Au}$ 와 $\mathrm{Al}$ 의 상호확산 속도의 차이와 형성된 $\mathrm{IMC}$ 와의 부피 차에 의해 형성되는데, $\mathrm{Au}-\mathrm{Ag}-\mathrm{Pd}$ 합 금 와이어의 경우 $\mathrm{Au}-\mathrm{Al}$ 층의 아래에 $\mathrm{Au}-\mathrm{Ag}-\mathrm{Al}$ 층이 형성되면서 $\mathrm{Au}-\mathrm{Al}$ 상호확산 반응을 감소시켰다. 본 연 구에서도 $\mathrm{Au}$ 와이어 접합부에서 관찰된 Kirkendall Void는 약 5 개가 관찰되었고, $\mathrm{Au}-\mathrm{Ag}-\mathrm{Al}$ 층이 형성된 $\mathrm{ACA}$ 와이어 접합부에서는 약 1 개로 $\mathrm{Au}$ 와이어 접합 부보다 적게 관찰된 것으로 보아 $\mathrm{Ag}$ 의 함량이 커켄달 보이드를 방지하는데 효과적인 것을 알 수 있었다.

\section{4. 결 론}

본 연구에서는 $97.3 \% \mathrm{Ag}, \mathrm{Au}$-coated $97.3 \%$ $\mathrm{Ag}(\mathrm{ACA}), 99.99 \% \mathrm{Au}$ 소재를 사용한 $20.32 \mu \mathrm{m}$ (0.8 mil) 와이어를 사용하여 볼 본딩 및 스티치 본딩 하여 Dummy 패키지를 제작하였다. $130^{\circ} \mathrm{C}, 85 \% \mathrm{RH}$ 조건의 $\mathrm{HAST}$ 시험을 진행하여 시험 전/후의 $\mathrm{BST}$ 및 $\mathrm{BPT}$ 를 측정하였으며, 와이어의 초음파 접합부 미세조 직 특성변화를 비교하였다.

1) $\mathrm{BST}$ 결과 초기 접합강도는 약 23-24 gf로 유사 하였지만, HAST 시험 후 $\mathrm{Ag}, \mathrm{ACA}$ 및 $\mathrm{Au}$ 와이어 접 합강도는 각각 약 $75 \%, 47 \%, 17 \%$ 감소하였다.

2) 미세조직 분석결과 균열은 접합부 끝에서 발생하 여 전파되었고, $\mathrm{ACA}$ 및 $\mathrm{Au}$ 와이어의 접합부에서 $\mathrm{Au}$ 함량이 많은 $\mathrm{Au}-\mathrm{Al}$ 금속간화합물이 균열의 전파를 억 제하는 것으로 판단되었다.

3) $\mathrm{Au}$ 와이어 접합부에서 Kirkendall Void가 관찰 되었고, $\mathrm{ACA}$ 와이어 접합부에서는 거의 관찰되지 않 았다. $\mathrm{ACA}$ 와이어 접합부에서 형성된 $\mathrm{Ag}-\mathrm{Au}-\mathrm{Al}$ 금 속간화합물이 $\mathrm{Au}-\mathrm{Al}$ 상호확산 반응의 장애물로 작용하 여 Kirkendall Void 발생을 감소시키는 것으로 사료 된다.

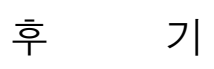

본 연구는 경기도와 (재)차세대융합기술원에서 지원 한 소재·부품·장비산업 자립화 연구지원사업 (과제번 호: AICT-010-T2)의 지원을 받아 수행된 연구결과입 니다.
ORCID: Mi-Song Kim: https://orcid.org/0000-0002-4717-9365 ORCID: Won Sik Hong: http://orcid.org/0000-0001-8398-177X ORCID: Sang Yeop Kim: https://orcid.org/0000-0001-7371-5718 ORCID: Sung Min Jeon: https://orcid.org/0000-0001-6685-8796

\section{References}

1. J. P. Jung, Ultrasonic Bonding of Electronic Parts, Proceedings of the 2008 Autumn Meeting of KWJS, Incheon (2008) 7-9.

2. J. Y. Park, C. M. Oh, D. H. Won, and W. S. Hong, Ultrasonic Bonding Property of Aluminium Wire for Power Conversion Module of Automotive, J. Weld. Join., 36(3) (2018) 57-64. https://doi.org/10.5781/JWJ.2018.36.3.9

3. M. Schneider-Ramelow, C. Ehrhardt, The reliability of wire bonding using $\mathrm{Ag}$ and $\mathrm{Al}, \mathrm{J}$. Microelectron. Reliab. 63 (2016) 336-341. http://dx.doi.org/10.1016/j.microrel.2016.05.009

4. P. Lall, S. Deshpande, and L. Nguyen, Reliability of Copper, Gold, Silver, and PCC Wirebonds Subjected to Harsh Environment, Proceedings of Electronic Components and Technology Conference (ECTC), IEEE 68th (2018) 724-734. https://doi.org/10.1109/ECTC.2018.00113

5. N. B. Jaafar and E. W. L. Ching, Comparison of Au/Al, $\mathrm{Cu} / \mathrm{Al}$ and $\mathrm{Ag} / \mathrm{Al}$ in Wirebonding Assembly and IMC Growth Behavior, Proceedings of Electronics Packaging Technology Conference (EPTC), IEEE 18th (2016) 10-12. https://doi.org/10.1109/EPTC.2016.7861432

6. J. M. Kim, J. P. Jung, S. H. Kim, and J. H. Pack, Packaging Technology in Electronics and 3-dimensional Stacking Packaging, J. Korean Weld. Join Soc., 23(2) (2005) 23-31.

7. Y. W. Tseng, F. Y. Hung, and T. S. Lui, Wire bonding of $\mathrm{Au}$-coated Ag wire, bondwire properties, bondability and IMCs formation, Proceedings of European Microelectronics Packaging Conference (2015) 1-4.

8. H. Yang, K. Cao, X. T. Zhao, W. Liu, J. Lu, and Y. Lu, Brittle-to-ductile transition of $\mathrm{Au}_{2} \mathrm{Al}$ and $\mathrm{AuAl}_{2}$ intermetallic compounds in wire bonding, J. Mater. Sci.: Mater. Electron. 30 (2019) 862-866. https://doi.org/10.1007/s10854-018-0357-6

9. H. Liu, Q. Chen, Z. Zhao, Q. Wang, J. Zeng, J. H. Chae, and J. S. Lee, Reliability of Au-Ag Alloy Wire Bonding, Proceedings of Electronic Components and Technology Conference(ECTC), IEEE 60th (2010) 234239.

https://doi.org/10.1109/ECTC.2010.5490906 